\title{
Onboarding The Faculty: A Model For Win-Win Mentoring
}

Susan Eisner, Professor of Management, Anisfield School of Business, Ramapo College of New Jersey, USA

\begin{abstract}
Literature finds mentoring to be a substantive, enduring practice in widespread arena, and among the attributes associated with career success and satisfaction. This paper provides a tangible mentoring model that has been operational for several years, and which applies what the literature proscribes to higher education academic settings. The Faculty Mentoring Program (FMP) this paper describes was created by the faculty at an AACSB-accredited School of Business at a mid-sized public regional college $e^{i}$ as the School anticipated transitions attendant to that accreditation. FMP objectives are consistent with those of mentoring programs interested in optimizing performance and satisfaction of new entrants in any workplace setting, and the reviewed secondary literature establishes and indicates the transferability of FMP core planks to other workplace settings. The phases used to operationalize, assess, and revise that FMP are reported along with strategies used to optimize its reception, impact, and outcomes should that be helpful to those considering if such a construct might be beneficial to pursue in their own settings.
\end{abstract}

Keywords: Mentoring Model; Faculty Mentoring Program; Mentoring Faculty

\section{INTRODUCTION}

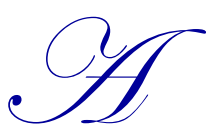

ccording to the Merriam-Webster Dictionary, a mentor is "a trusted counselor or guide." The term is said to be derived from the Latin rooted in the Greek "Mentor," who is described as "a friend of Odysseus entrusted with the education of Odyssesus' son Telemachus;" its first known use is noted as $1616^{\mathrm{ii}}$." Almost 400 years later, a Google search for the keyword mentor produces some 149,000,000 results, for mentor program produces 39,800,000 results, and for mentoring programs for new faculty produces 7,030,000 results. Business books ranging from Robbins and Judge's Organizational Behavior (2013) to Dubrin's Leadership (2013) and_Allen et al.'s Workplace Mentoring Programs (2009) describe the contemporary usage of mentoring programs for employee development, and non-profit research and consulting organizations such as Catalyst positively associate mentoring with career success (Carter and Silva, 2010). Two recent Corner Office columns in the New York Times Sunday Business section were titled "A Good Mentor Never Tramples on Big Dreams iii, and "When I Hire You, I'm Hiring Your Mentors' Judgment ${ }^{\mathrm{iv}}$." And businesses are implementing systematic "onboarding" programs to help new employees optimize performance by forming relationships and accessing central information from the start (Derven, 2008; The 10 Commandments of Employee Onboarding, n.d.). The concept of mentoring appears to be a substantive, enduring practice and in widespread arena.

\section{FMP: A MODEL FOR WIN-WIN MENTORING}

The goal of this paper is to provide a model for a Faculty Mentoring Program (FMP) that applies to higher education academic settings what the literature proscribes as optimal mentoring attributes overall. The paper will describe the FMP designed, implemented, and assessed by the faculty at an AACSB-accredited school of business in a mid-size, well-ranked ${ }^{v}$ public regional college located in the tri-state New York area, the Anisfield School of Business (ASB) at Ramapo College of New Jersey. FMP has been operational for some nine years. It may be especially useful as a model as it developed and operates in an institution that does not have a university-wide faculty mentoring program, originated from and is directed by faculty, and is neither resource intensive nor dependent on external funding. 
This FMP was conceived as ASB faculty began to transition, as many do, during initial planning for AACSB accreditation. Having heard from colleagues at other schools who had experienced that transition with various degrees of cultural and functional impact, some ASB Management faculty envisioned the constructive role a formal mentoring program might play at the school. The resulting FMP was designed to achieve this objective:

The stated purpose of ASB'S FMP is to provide all untenured ASB faculty with access to a tenured ASB faculty member to support achievement of the incoming faculty member's goals, to facilitate the incoming faculty member's acculturation to ASB and Ramapo College, and to optimize collegiality and community within ASB and Ramapo College $e^{v i}$.

ASB's FMP intentionally assesses its performance annually, redesigns to optimize impact based on outcomes, and continually evolves to accommodate current faculty and programmatic needs. From the start, it has been positively responded to by participants ${ }^{\mathrm{vii}}$. Entering faculty, who have been selected from competitive nationwide searches and whose prior affiliations reflect a variety of academic institutions, describe FMP as a strength, help, and competitive advantage. They say their prior institutions, and their peers at other institutions, do not have a program like it ${ }^{\text {viii }}$.

Delivering these results stemmed from a mindful, strategic process that encountered both expected and unexpected challenges it determined to convert to opportunities. This paper presents the FMP in its current, advanced state for those who might want to consider adapting it to their own institutions. It also presents the developmental stages through which that FMP has traversed for those whose own adaptive experience might be facilitated as a result.

\section{PURPOSE AND METHOD}

The primary purpose of this paper, then, is to offer a tangible model for those considering whether an FMP is a construct that might be beneficial to pursue in their own settings. As FMP objectives are consistent with those of mentoring programs interested in optimizing performance and satisfaction of new entrants in any workplace setting, as the reviewed secondary literature spans the mentoring literature overall, and as that literature establishes and indicates the transferability of FMP core planks to other workplace settings, the paper may be useful to those in both academic and non-academic environs. In addition to describing the FMP model its operative programs, assessment tools and guidelines for optimization are presented. Academic and practitioner literature on mentoring programs, onboarding, and faculty mentoring has been consulted and is referenced. Results of primary research assessing FMP effectiveness and subsequent initiatives implemented are reported.

The paper continues groundwork that was laid in several prior papers ${ }^{\mathrm{ix}}$ by its author as well as in a recent authored book chapter ${ }^{x}$. Collectively the research identified that organization and employee must both be satisfied, and common ground found between them, for their relationship to be sustainable. That research also found mentoring to be among the attributes associated with career success and satisfaction. This paper, as a result, seeks to contribute to business and management literature, practice, and education through current primary research conducted within a framework constructed from relevant secondary literature.

\section{LITERATURE REVIEW}

The literature base for considering implementation of a faculty mentoring program at institutions of higher learning is well established and far-reaching. Savage et al.'s conclusion that research has long shown a real need for faculty mentoring cites the American Association for Higher Education as indicating that good practice at colleges and universities encourages mentoring by senior faculty ${ }^{\mathrm{xi}}$ (2004). Ramani et al. report that mentoring programs are positively associated with faculty retention (2006). Ehrich et al.'s more recent meta-review of the mentoring literature found positive outcomes for both mentor and mentee, and cited Gardiner's 2007 findings that mentoring delivers higher rates of retention and promotion, more success in receiving external research grants, higher publication rates, and better perception of self as an academic (2011). 
Cariaga-Lo et al. summarized the vital role faculty mentoring plays this way: "Mentoring and creating an inclusive academic climate is critical to developing scholars at all stages of the academic career ladder, which contributes to building academic excellence at our institutions" (2010). Given that potential contribution, McClurken's hesitant note is equally important to consider: "Having a faculty mentoring program does not necessarily mean effective mentoring is occurring" (2009).

The above findings underscore that having a mentoring program does not per se indicate that potential positive outcomes will be achieved. The program must be conceived, assessed, and revised, as best practice for program design proscribes, with identified goals and effective practices operationalized and continually reconfigured if assessment so indicates. Dervin's work indicates why doing so is nonetheless worthwhile. She reports that a "sink or swim" approach to onboarding, in which newcomers are left to sort things through and find their way for themselves, does not fit today's rapid rate of change and complex institutions. Rather, fostering bonding and overcoming "silos," as effective mentoring does, facilitates talent management (2008). Others explain potential benefits of effective onboarding in financial terms. The International Institute for Management Development, for example, found that businesses in the United States and United Kingdom lose about $\$ 37$ billion each year because their workers do not fully understand their jobs (The 10 Commandments of Employee Onboarding, n.d.).

While the mentoring literature is foundational and clear, it is rather redundant in coverage and content. Although it is not the main intent of this paper to be one more synopsis of the literature, that research base is summarized in Table 1, below, and also categorized here for those who may find having done so a resource. The literature essentially falls into one of these categories: characteristics of effective mentoring programs and their participants (including Boyle and Boice, 1998; Mellon, 2003; Savage et al., 2004; McCauley, 2007; Sorcinelli and Jung, 2007; Chao, 2009; Bell and Treleaven, 2011; Borders et al., 2011), advocacy for and reservations about mentoring programs (including Boyle and Boice, 1998; Subha, 2006; McClurken, 2009; Bell and Treleaven, 2011; Borders et al., 2011; Hanuka, 2012), and examples of specific mentoring programs (Boyle and Boice, 1998; Savage et al., 2004; Chao, 2009; Cariaga-Lo et al., 2010). Additionally, websites of several colleges and universities that have faculty mentoring programs contain publicly available program descriptions and guidelines for their programs' participants. A representative sample of those online resources and their links are in this paper's endnotes ${ }^{\mathrm{xii}}$.

Table 1: Mentoring Literature Summary

\begin{tabular}{|l|l|}
\hline \multicolumn{1}{|c|}{ ATTRIBUTE } & \multicolumn{1}{c|}{ LITERATURE SUMMARY } \\
\hline Goals and Objectives & Career, psycho-social, modeling \\
\hline Program Communication & $\begin{array}{l}\text { Clarify goals, objectives, expectations, and confidentiality; make available and coordinate } \\
\text { with relevant informational documents }\end{array}$ \\
\hline Program Administration & $\begin{array}{l}\text { Formal programs are managed by administrators, department chairs, or faculty; informal } \\
\text { mentoring reflects faculty choices; mentoring may be 1-1, hierarchical or peer, and/or } \\
\text { broad-based/combination }\end{array}$ \\
\hline Expectations for Participants & $\begin{array}{l}\text { Formal programs define expectations; informal mentoring is based on expectations } \\
\text { reflected in the choice to pair }\end{array}$ \\
\hline Attributes of Mentors & $\begin{array}{l}\text { Mentors can be faculty, administrators, or staff; they can be hierarchical or peer, they can } \\
\text { serve in a 1-1 pair or in a pool }\end{array}$ \\
\hline Attributes of Mentees & $\begin{array}{l}\text { Formal programs mentor untenured faculty and vary in years mentees are included (range } \\
\text { from 1st year only to 1st year through tenure) }\end{array}$ \\
\hline Matching Mentor with Mentee & $\begin{array}{l}\text { Formal programs match through program's head, mentor's choice, or mentee's choice } \\
\text { which may be selecting from a pool of mentors; informal mentoring reflects choices of } \\
\text { mentor and mentee }\end{array}$ \\
\hline Meetings & $\begin{array}{l}\text { Formal programs' meetings vary from those mentor pairs schedule to those the program } \\
\text { schedules which may include collective sessions; informal mentoring occurs at a mentor } \\
\text { pair's choice }\end{array}$ \\
\hline Including Non-Paired Faculty & $\begin{array}{l}\text { Formal programs determine who is included which may include all; informal mentoring } \\
\text { includes those wanting and able to pair }\end{array}$ \\
\hline Outreach & $\begin{array}{l}\text { Some formal programs provide incentives that reward and recognize participation in } \\
\text { mentoring program; that may include providing reassigned time to participants }\end{array}$ \\
\hline Program Feedback & $\begin{array}{l}\text { Formal programs vary in type of feedback solicited; regular and ongoing assessment of } \\
\text { formal programs is recommended }\end{array}$ \\
\hline Program Revision & Some formal programs redevelop based on experience/feedback \\
\hline
\end{tabular}


Boyle and Boice's findings may be of particular interest to those interested in facilitating faculty mentoring. They report results of a two-year pilot program conducted simultaneously on two different campuses that made possible comparison of alternate mentoring approaches. They found participation strong in both programs, mentor pairs with mentor from different departments than mentee more effective than mentor pairs with mentor and mentee from the same department, mentor pairs with more senior mentors more effective than mentor pairs with less senior mentors, and group meetings for all mentors and mentees the most favored and highly favored aspect of the program. They also found systematic, structured (formal) mentoring to be more effective than spontaneous (informal) mentoring. Mentor pairs systemically formed met more regularly, met over a longer period of time, and experienced greater program involvement than did mentor pairs spontaneously formed. Moreover, the structured program was more likely to involve mentors and mentees typically left out of informal mentoring processes (1998).

\section{OPERATIONALIZING A FACULTY MENTORING PROGRAM}

Existing literature, then, is robust descriptively. Those considering construction and implementation of a mentoring program at their own institutions may find it helpful to know the steps that doing so involved at a School of Business whose faculty chose to do so. The Faculty Mentoring Program (FMP) at the Anisfield School of Business (ASB) was implemented in four phases, over a period of several years, and remains operational today. At the outset, only the first phase was conceptualized. The other three phases emerged experientially.

\section{Phase I: Pilot the Program}

The initial design of ASB's FMP was conceptualized by a Task Force of three tenured faculty members, all of whom then had been at the School between five and eight years. The Task Force was one of several operating simultaneously as the School engaged in strategic planning as part of its preparation for AACSB accreditation candidacy. The charge of each Task Force was identified by the School's Dean, a tenured Management professor prior to becoming Dean; faculty members volunteered to serve on Task Forces for which they felt most interest and ability to contribute, and Task Forces were to report their recommendations to the School's whole faculty for approval. The Task Force that conceived and recommended FMP was charged with faculty development and support. Two of its three members were Management professors ${ }^{\text {xiii }}$, and the third was a Finance professor. Each of these had prior practitioner experience, and none had worked at colleges which had mentoring programs for faculty.

The FMP recommended by the Task Force identified faculty development, support, retention, acculturation, and community as its goals, and confidentiality among FMP participants was to be assured. All untenured faculty members were to be provided access to faculty mentors; each of these untenured "mentees" would be paired one-to-one with a tenured faculty mentor. The mentor would be a member of the Task Force, from a department other than the mentee's department to avoid conflict of interest and to broaden exposure/community, and matched with his/her mentee by the Task Force prior to the start of the academic year. To inform that pairing, the Task Force would consult the Dean, who was part of the Search Process and the Task Force was not, about the developmental needs and interests of each incoming faculty member.

Each resulting mentor-mentee pair (e.g. mentor pair) would determine when and how often it would meet during the academic year, and would formulate its own objectives and expectations within the overall framework of faculty development, support, retention, acculturation, community, and confidentiality established as FMP goals. The pairing would be in place until the mentee reached tenure; its experience would guide any changes that would better serve it. This iteration, titled the New Faculty Mentorship Program, sought to strike a balance between formal and informal mentoring. Seeking such balance was intentional, as faculty consensus seemed to emerge more naturally for an FMP in which pairs would have considerable operational leeway. The New Faculty Mentorship Program was approved when recommended by the Task Force to the School's whole faculty, supported by the Dean, and implemented the following academic year. 


\section{Phase II: Experience the Program}

As it turned out, and in retrospect, the New Faculty Mentorship Program was in fact a Pilot Program. In its first operational year, several strengths and weaknesses surfaced. Strengths included a more seamless transition to the faculty for those joining it, heightened engagement of mentors, broadened familiarity between incoming faculty and ongoing faculty, expedited exposure of untenured faculty to those outside their immediate departments, widened and more inclusive sense of cohort group, and an overall strengthened sense of community among the School's faculty.

However, it also emerged that the vision for sourcing mentors was flawed. The Task Force had only three tenured members/mentors, and there were at least 12 untenured faculty members/mentees. That meant each mentor would serve in at least four mentor pairs, and some mentor pairs would have faculty from the same department. Moreover, there were tenured faculty members not on the Task Force interested and available to serve as mentors, and not every faculty member on the Task Force mentored in a way sufficient for the mentee. The more the mentor was inclined toward informal mentoring, the less mentoring tended to occur, and the less satisfied the mentee tended to be. This was expressed behaviorally (the mentee was more disengaged), in disappointment about some mentees' lack of initiative expressed to the Task Force by mentors, and in disappointment about the FMP and some of its mentors expressed to those outside the Task Force by some of the mentees.

Additionally, mentors found they were being asked similar foundational questions by their mentees, some of what they were being asked such as criteria for tenure and promotion was the formal purview of others to provide and assess, and some of what mentors were being asked about was outside their expertise or comfort level to provide. Finally, some mentors found more time was needed to mentor than they had anticipated or could provide, and some mentors felt this service to be less rewarded and valued by administration and colleagues than other activities they might be performing instead.

At the end of the Pilot's early years, the School gained a different and interim Dean. The new Dean had been a faculty member at the School for a short time, had taught at several other institutions before joining this faculty, and had been a mentee in the FMP Pilot. The new Dean was amongst those whose mentor had taken an informal approach to their pairing. Based on the mentoring he himself had had, the new Dean was at best skeptical as to whether the FMP was fulfilling its charge.

\section{Phase III: Revise the Program}

As a result of this feedback, the Task Force revisited the FMP and recommended its revision. The charge, goals, objectives, and pairing of mentor and mentee from different departments were retained as experience had confirmed these to be strengths. Several steps were taken, though, to address unforeseen operational shortcomings that had emerged. To strengthen program administration and communication the Task Force chose one of its members as FMP Chair. All tenured members of the School's faculty were invited to volunteer as mentors, enabling fulfillment of the primary unmet need remaining for the Task Force and for which it had too few members to perform. Faculty Search Committee Chairs as well as the Dean would be consulted about the development needs and interests of entering faculty. The pool of available mentors would then be reviewed, informed by that input, for optimal pairing of mentor and incoming mentee by FMP Chair. The Task Force, having fulfilled its charge, naturally disbanded.

To strengthen the mentoring and provide it in ways reflecting the career step of each mentee, $1^{\text {st }}$ year faculty would be paired with a mentor who appeared to be well suited, $2^{\text {nd }}$ year faculty could continue with that mentor or - with no retribution - request a mentor more suited to their emergent priorities, and faculty $3^{\text {rd }}$ year through tenure would be provided access to a mentor pool of all tenured faculty interested and available to mentor that year whom could be approached informally for any issue or duration; confidentiality would be assured throughout. A luncheon for $1^{\text {st }}$ and $2^{\text {nd }}$ year mentor pairs would be held to kick off each academic year, facilitate introductions, train participants in FMP goals and procedures, and clarify expectations. A luncheon would also be held at the end of each academic year to celebrate the year's completion; certificates of participation would be 
distributed at that year-end event, which would be announced and open to all the School's faculty. The Dean would finance and be invited to attend the lunches, and jointly sign the certificates with the FMP Chair.

Additionally descriptions of and links to programs and resources within the School and wider College, ranging from personnel committees to grant allocating committees, that were outside the purview of mentoring but had surfaced as common queries of mentees would be compiled by the FMP Chair and distributed early in the academic year to mentor pairs. Research areas and interest in collaborating on research would be solicited of all the School's faculty, compiled, and distributed to mentor pairs by the FMP Chair. A collective "teaching roundtable" addressing common interests and sharing experiences of the School's faculty relating to teaching, student learning, and classroom management would be hosted each semester by the FMP Chair, and a personnel orientation session co-hosted by the FMP Chair and the School's Personnel Committees Chairs would be held in the first semester of each academic year. Collective sessions would be announced and open to all School faculty; mentor pairs would meet one-to-one for one-half hour immediately before or after each collective session. Each mentor would schedule an off-record visitation of his/her mentee teaching in the Fall semester, and de-brief with the mentee immediately thereafter; each mentee would schedule an off-record reverse visitation of his/her mentor teaching in the Fall semester and de-brief with the mentor immediately afterward.

Mentors would meet together with the FMP Chair at the start of the academic year to review operational aspects, and the FMP Chair would intentionally touch base mid-year with each mentor and mentee to gather and respond to any midyear feedback. A one-page list itemizing three benchmark meetings for each mentor pair to be called by the mentor each year, with subsequent meetings at the mentee's initiative and choice, and also itemizing each of the collective sessions for all School faculty, would be distributed to the faculty at the start of the academic year by the FMP Chair.

Finally, a questionnaire was designed and would be circulated among all FMP participants at the end of each academic year so that feedback on impact and effectiveness would be formally and anonymously received by the FMP Chair. Results of that feedback would be shared in an annual report that would be distributed by the FMP Chair to the School's faculty and Dean. This revised FMP continued to seek balance between formal and informal aspects of mentoring but it reconceived their operationalization in a way that experience with the Pilot suggested would strengthen FMP effectiveness.

This revised program, renamed the Faculty Mentoring Program, was approved by the School's faculty and implemented the following academic year. It has been chaired by the same tenured faculty member since its implementation, at the request of program participants. The pool of mentors, and mentors paired with $1^{\text {st }}$ and $2^{\text {nd }}$ year faculty, changes incrementally annually, also reflecting the interests and requests of program participants.

The Dean who replaced the Interim Dean was from outside the College, new to academics, and a former corporate executive. The revised FMP was in place when he arrived. He is regularly informed and consulted, and has provided all support requested by the FMP Chair. Table 2 below summarizes key FMP attributes as piloted and as revised. 
Table 2: Faculty Mentoring Program At ASB - Piloted And Revised

\begin{tabular}{|c|c|c|}
\hline ATTRIBUTE & $\begin{array}{c}\text { PILOTED } \\
\text { New Faculty Mentorship Program }\end{array}$ & $\begin{array}{c}\text { REVISED } \\
\text { Faculty Mentoring Program }\end{array}$ \\
\hline $\begin{array}{l}\text { Goals and } \\
\text { Objectives }\end{array}$ & $\begin{array}{l}\text { Faculty development, support, retention, } \\
\text { acculturation, community; confidentiality }\end{array}$ & Unchanged \\
\hline $\begin{array}{l}\text { Program } \\
\text { Communication }\end{array}$ & Written program description is given to all faculty & $\begin{array}{l}\text { Description, report/update, samples, links, schedule } \\
\text { are given to all faculty }\end{array}$ \\
\hline $\begin{array}{l}\text { Program } \\
\text { Administration }\end{array}$ & $\begin{array}{l}\text { Task force of three tenured faculty; program is } \\
\text { approved by all faculty }\end{array}$ & $\begin{array}{l}\text { Faculty select tenured faculty member as FMP } \\
\text { Chair; program is approved by all faculty; Dean is } \\
\text { informed/ involved; participants are trained }\end{array}$ \\
\hline $\begin{array}{l}\text { Expectations } \\
\text { for Participants }\end{array}$ & $\begin{array}{l}\text { Informal and to align with program goals and } \\
\text { objectives }\end{array}$ & $\begin{array}{l}\text { Formal guidelines are provided within which pairs } \\
\text { define outcomes }\end{array}$ \\
\hline $\begin{array}{l}\text { Attributes of } \\
\text { Mentors }\end{array}$ & $\begin{array}{l}\text { Task force members serve as mentors paired 1-1 } \\
\text { with mentees of different departments }\end{array}$ & $\begin{array}{l}\text { All tenured faculty can mentor; mentor suits mentee } \\
\text { needs, and should not be from mentee's department }\end{array}$ \\
\hline $\begin{array}{l}\text { Attributes of } \\
\text { Mentees }\end{array}$ & $\begin{array}{l}\text { Untenured faculty are each paired 1-1 with a } \\
\text { faculty mentor; mentoring is informal after tenure }\end{array}$ & $\begin{array}{l}1^{\text {st }} \text { and } 2^{\text {nd }} \text { year faculty are each in a } 1-1 \text { pair with a } \\
\text { faculty mentor; mentoring is informal } 3^{\text {rd }} \text { year-tenure }\end{array}$ \\
\hline $\begin{array}{l}\text { Matching } \\
\text { Mentor with } \\
\text { Mentee }\end{array}$ & $\begin{array}{l}\text { Consult Dean re: salient developmental needs and } \\
\text { interests of new faculty member; pair each new } \\
\text { faculty member with a mentor best suited to } \\
\text { provide that }\end{array}$ & $\begin{array}{l}\text { Consult Dean and faculty Search Chair re: } \\
\text { need/interest of new faculty; pair } 1^{\text {st }} \text { year mentee } \\
\text { with mentor who best fits; } 2^{\text {nd }} \text { year mentee requests } \\
\text { mentor; } 3^{\text {rd }} \text { year-tenure mentee can seek out any } \\
\text { tenured faculty mentor }\end{array}$ \\
\hline Meetings & Mentor pairs decide when and how often to meet & $\begin{array}{l}\text { Benchmark meetings are set for all mentor pairs } \\
\text { coinciding with collective sessions for all faculty }\end{array}$ \\
\hline $\begin{array}{l}\text { Inclusion of } \\
\text { Non-Paired } \\
\text { Faculty }\end{array}$ & $\begin{array}{l}\text { No role for faculty who are not in a mentor-mentee } \\
\text { pair }\end{array}$ & $\begin{array}{l}\text { All tenured faculty can mentor, all untenured faculty } \\
\text { can be mentored, all faculty can attend collective } \\
\text { sessions }\end{array}$ \\
\hline Outreach & None & $\begin{array}{l}\text { Call sessions with Personnel and with Research } \\
\text { Committees for all; include Dean and faculty } \\
\text { Department heads in sessions that inform or } \\
\text { recognize }\end{array}$ \\
\hline $\begin{array}{l}\text { Program } \\
\text { Feedback }\end{array}$ & Informal & $\begin{array}{l}\text { Year-end anonymous questionnaire to participants; } \\
\text { results in annual report to Dean and faculty; FMP } \\
\text { Chair debriefs each mentee and mentor midyear }\end{array}$ \\
\hline $\begin{array}{l}\text { Program } \\
\text { Revision }\end{array}$ & NA - Pilot Program & $\begin{array}{l}\text { Ongoing; all feedback has been thoughtful, on point, } \\
\text { and acted on; feedback has strengthened Program }\end{array}$ \\
\hline
\end{tabular}

\section{Phase IV: Assess and Optimize the Revised Program}

The initial charge of the Task Force that conceived and recommended the FMP was faculty development and support. Retention, acculturation, and community were also itemized from the start as FMP objectives. To the extent that turnover is a measurable indicator, retention has been strong. Untenured faculty, both those whom have taught elsewhere and recent Ph.D.s, have reported to the FMP Chair that FMP is a positive factor in their decision to stay at ASB. The few whom having been mentored have left the School say they have done so to relocate or to be at an institution whose primary focus is research rather than teaching. They report that FMP participation bonded them so strongly to this School that the decision to leave was not easy.

Another measurable indicator of objective's achievement is faculty participation rate. Table 3, below, summarizes the participation of the School's faculty in its revised FMP. The number of "other active mentors" is a conservative number reflecting those actively contributing as mentors at collective FMP sessions. It does not reflect the mentoring being provided by those sought out as mentors by mentee choice informally, and so not reported, by faculty in $3^{\text {rd }}$ year to tenure. The majority of the School's faculty members are participating in its FMP annually. 
Table 3: Participation In Faculty Mentoring Program (Required Of $1^{\text {st }}$ And $2^{\text {nd }}$ Year ASB Faculty)

\begin{tabular}{|l|c|c|c|c|c|}
\hline & $\begin{array}{c}\# \mathbf{1}^{\text {st }} \\
\text { Mentees (Required) }\end{array}$ & $\begin{array}{c}\text { \# 3 } \mathbf{3}^{\text {rd }} \text { Year to Tenure } \\
\text { Mentees (Not Required) }\end{array}$ & $\begin{array}{c}\text { \# Mentors Paired } \\
\text { to Mentees }\end{array}$ & $\begin{array}{c}\text { \# Other } \\
\text { Active Mentors }\end{array}$ & $\begin{array}{c}\text { Total \# } \\
\text { FMP Faculty }\end{array}$ \\
\hline AY'09-'10 & 8 & 4 & 7 & $3+$ & $22+$ \\
\hline AY'10-'11 & 12 & 4 & 11 & $2+$ & $29+$ \\
\hline AY'11-'12 & 7 & 9 & 7 & $1+$ & $24+$ \\
\hline AY'12-'13 & 4 & 11 & 4 & $2+$ & $21+$ \\
\hline
\end{tabular}

A further indicator of outcomes delivered is the feedback provided by FMP participants in the year-end questionnaire which they complete anonymously. The 2011-2012 year-end questionnaire included questions probing specific initiatives intended to be furthered by the revised FMP after the initiatives had been operationalized sufficiently for more than one-time-only experience to have occurred. Although number of responses to the yearend questionnaire varies, reflecting the tendency of those who have participated in prior years to feel it redundant to reply again unless their feedback significantly changes, results are similar each year and suggest virtual agreement that the initiatives being provided by the revised FMP are valued by its participants. Both mentee and mentor respondents appear to value FMP roundtables and support about teaching/student issues particularly highly, and to also agree that both acculturation and information/support about personnel processes/procedures provided by FMP is highly valued. Research roundtables and support appear to be less though still valued, perhaps reflecting that the School has operationalized a separate Research Seminar. As such, FMP now focuses less on providing research support and more on the areas participants report they value most. Table 4, below, details those results.

Table 4: Participant Responses To End-Year 2011-2012 FMP Quantitative Assessment (\#; \%)

\begin{tabular}{|l|c|c|c|c|c|c|}
\hline Quantitative Questions & \multicolumn{2}{|c|}{ (9) Mentees Replied } & \multicolumn{3}{c|}{ (3) Mentors Replied } \\
\hline FMP Aspects & Low & Average & High & Low & Average & High \\
\hline Acculturation to school/faculty & 0 & $2 ; 22 \%$ & $7 ; 78 \%$ & 0 & $1,33 \%$ & $2 ; 67 \%$ \\
\hline Personnel process info./support & $1 ; 11 \%$ & $2 ; 22 \%$ & $5 ; 67 \%$ & 0 & $1,33 \%$ & $2 ; 67 \%$ \\
\hline Research roundtables/support & $1 ; 11 \%$ & $5 ; 56 \%$ & $3 ; 33 \%$ & 0 & $1,33 \%$ & $2 ; 67 \%$ \\
\hline Teaching roundtables/support & 0 & $2 ; 22 \%$ & $7 ; 78 \%$ & 0 & 0 & $3 ; 100 \%$ \\
\hline
\end{tabular}

The year-end questionnaire also provides open-ended questions so that unprompted suggestions and/or concerns can surface that might optimize FMP through further modifications or initiatives. Table 5, below, summarizes the qualitative responses to the open-ended questions. While the majority of responses indicate that the revised FMP is delivering what its participants seek, several respondents offered thoughtful and helpful suggestions that had not been considered previously and which have stimulated initiatives now integral to FMP.

Table 5: Participant Responses To End-Year FMP Qualitative Assessment

\begin{tabular}{|l|c|c|c|c|c|c|}
\hline \multicolumn{2}{|c|}{ Qualitative Questions } & \multicolumn{3}{c|}{ 2010 Replies (8)* } & \multicolumn{3}{c|}{ 2011 Replies (12)* } \\
\hline & As Is & Suggest & Act On & As Is & Suggest & Act On \\
\hline Most beneficial aspects of FMP & 8 & 0 & NA & 12 & 0 & NA \\
\hline Ways FMP could be improved & 5 & 3 & 3 & 6 & 6 & 6 \\
\hline Gaps in services/support provided & 7 & 1 & 1 & 11 & 1 & 1 \\
\hline Additional services you recommend & 5 & 3 & 3 & 10 & 2 & 2 \\
\hline Sufficiency of mentor pair practices & 7 & 1 & 1 & 9 & 3 & 3 \\
\hline Tenured faculty to add to mentor pool & 8 & 0 & NA & 10 & 2 & 2 \\
\hline Other suggestion to strengthen FMP & 6 & 2 & 2 & 9 & 3 & 3 \\
\hline Your mentor pair was well matched & 8 & 0 & NA & 12 & 0 & NA \\
\hline
\end{tabular}

Every comment made by year-end questionnaire respondents is considered as a potential recommendation for continual FMP improvement. Table 6, below, reports actions taken as a result of feedback provided by FMP participants. That feedback has proved invaluable in ongoing "loop closing" of FMP in ways that meet participant needs and might otherwise have gone undetected and unsupported. Resulting initiatives include creation of an FMP Checklist distributed to all faculty members at the start of each academic year. The FMP Checklist is updated annually and incorporates any new aspects stimulated by the feedback. A copy of the current FMP Checklist is appendixed to this paper. 
Table 6: Participant Suggestions To End-Year FMP Assessment And Actions Taken

\begin{tabular}{|c|c|}
\hline Comment/Suggestion & Action Taken \\
\hline $\begin{array}{l}\text { Schedule conflicts and time constraint can make it hard to set } \\
\text { mentor pair meetings }\end{array}$ & $\begin{array}{l}\text { Include mentor pair meetings in FMP schedule; schedule all } \\
\text { meetings on the common meeting day }\end{array}$ \\
\hline $\begin{array}{l}\text { Have more open-ended dialog/collective sessions with all } \\
\text { FMP participants }\end{array}$ & $\begin{array}{l}\text { Schedule at least } 2 \text { collective sessions each semester; invite } \\
\text { all ASB faculty }\end{array}$ \\
\hline Have more in-depth discussion at collective sessions & $\begin{array}{l}\text { Schedule collective sessions for } 1+\text { hour, and } 1 / 2 \text { hour mentor } \\
\text { pair meeting before or after }\end{array}$ \\
\hline Narrow down discussion topics & $\begin{array}{l}\text { Solicit agenda items from FMP participants in advance of } \\
\text { collective sessions }\end{array}$ \\
\hline $\begin{array}{l}\text { Hold roundtable discussions on teaching strategies/tips and } \\
\text { student learning/issues }\end{array}$ & $\begin{array}{l}\text { Schedule at least } 1 \text { Teaching Roundtable each semester; } \\
\text { invite all ASB faculty }\end{array}$ \\
\hline Include research interests in collective session & $\begin{array}{l}\text { Request ASB Research Seminar do this; make/circulate } \\
\text { faculty research interest list }\end{array}$ \\
\hline $\begin{array}{l}\text { Establish more formalized expectations/ } \\
\text { infrastructure for } 1-1 \text { pair operations }\end{array}$ & $\begin{array}{l}\text { Create/distribute checklist to mentors and mentees, and } \\
\text { debrief } 1-1 \text { at mid-term }\end{array}$ \\
\hline Provide monthly contact if new faculty are shy & Incorporate monthly sessions in schedule \\
\hline Say thank you to mentors & $\begin{array}{l}\text { Hold year-end lunch recognizing all FMP participants and } \\
\text { provide each with certificate }\end{array}$ \\
\hline Establish gathering place for ASB faculty & Request to Dean \\
\hline
\end{tabular}

\section{COMPLEXITY}

When the Task Force first recommended that ASB implement an FMP, the suggestion was largely intuitive. It did not derive from a literature search, and the experience other colleagues may have had with faculty mentoring was not queried. Rather the recommendation was an affirmative and enthusiastic response to the Task Force's charge that reflected the academic disciplinary areas and prior employment experiences of Task Force members.

As a result, it was in hindsight rather predictable that the initial recommendation would have some though insufficient merit. The benefits a mentoring program could deliver were on point. But what the Task Force's collective expertise did not sufficiently anticipate was the complexity of operationalizing an FMP that delivered those benefits. In retrospect what doing so entailed, once the vision had been formulated, was getting used to expecting the unexpected, recalibrating in response while still innovating proactively, and attuning to unanticipated problematic or opportune consequences - that is contingent, systemic, and creative thinking.

So the four phases detailed above were unanticipated at the start. They naturally emerged reflecting what the operationalized FMP was delivering. Collectively, they accommodated ten guidelines that surfaced:

1. Put someone in charge: An FMP is an intricate undertaking, and its outcomes are tied to career impacts for mentees and mentors. It is most likely to develop and deliver best when that result is the responsibility of an identified individual, who is interested and able to perform that responsibility and is credible to program participants. That individual should be comfortable with shepherding significant activities whose deliverables may go unacknowledged, given the confidentiality of an FMP.

2. Anchor it in the faculty: An FMP draws upon and is sustained by the peer-based culture of the academy. Administrators may change but the bulk of the tenured faculty is likely to remain, and it is faculty development and acculturation that FMP furthers. Faculty input, buy-in, feedback, and active participation are foundational to a robust FMP. Vesting its leadership in a faculty member further reflects and reinforces the core interest of the faculty in FMP success, and aligns accountability with that interest.

3. Give all a role to play: An FMP is deepened and broadened when it is inclusive. Outreach to all faculty and administrators in the untenured faculty's developmental chain, and construction of venues each has a contribution to make toward if interested, inoculates against unwitting creation of a two-tiered School. Rather, such outreach accesses the totality of the School's experiential and social capital resources, including good-will, and heightens a culture of ongoing development, shared growth, and community.

4. Ensure it is possible and important to participate: An FMP entails commitment of a resource everscarce for most participants - time. Citing participation as an activity that contributes to fulfilling one's academic service responsibilities is a start, as is providing an FMP Chair with re-assigned time and/or 
stipend equivalent to that provided to others responsible for ongoing School programs ${ }^{\mathrm{xiv}}$. Linking FMP participation with effort toward teaching effectiveness is also a plus, as is providing reassigned time to 1 st and 2nd year faculty for such activity if engaged in substantially and throughout the academic year.

5. Balance formal structure with spontaneous interaction: An FMP operates in an environment in which either informal mentoring previously was occurring, or in which informal mentoring previously was not occurring. If mentoring was not occurring spontaneously before, the formal structure will integrate mentoring into a School's infrastructure and culture and may create opportunities for informal mentoring to also occur. If informal mentoring was previously occurring, the formal structure should neither prohibit nor aim to replace it. Rather, the structure will supplement what had been occurring spontaneously with benefits a formal mentoring program can provide including access to inclusion for all, and opportunity for mentoring to occur between those well suited who might not otherwise have been paired.

6. Train participants and communicate 360: An FMP recognizes that effective mentoring involves more than intuition, good intentions, or even benevolence. Rather, it is a best practice that involves authenticity, empathy, candor, boundary-spanning, partnering, and courage as well as confidentiality and coaching. It clarifies vision, mission, guiding principles, and processes to all stakeholders; trains, resources, and supports participants; and fosters two-way communication throughout.

7. Make the tough calls: An FMP is only as effective as its participants experience it to be. It must be ready and willing to act in ways which may not be easy, fun, or even understood outside the bounds of confidentiality. A mentor pair may not be delivering for mentor or mentee, a mentee may not be progressing having taken the mentor's advice, a mentee may not be progressing having not taken the mentor's advice, participants may have privileged information that could impact outcomes, participants may breach confidences, a mentor may fear being professionally overshadowed by a mentee, those outside the program may provide conflicting information to that provided by participants, or those not choosing to participate may undermine it in some way. A viable, credible FMP will inoculate against such possibilities, but be alert for and responsibly manage any that occur.

8. Have no assumptions: An FMP is a work in progress. Its participants by definition will change and so by extension may needs and interests it seeks to serve. So FMP should assess expectations and outcomes regularly, through multiple formats that should also be periodically reviewed. Soliciting and rewarding those who provide information useful to FMP optimization should be evident practice; a shoot the messenger norm may backfire.

9. Adapt the mechanism: An FMP is constructed to operate and serve in a dynamic environment, and so will continually reshape to reflect any significant changes relevant to fulfilling its mission and optimizing its impact. Internal program assessment and feedback should be a starting point for ongoing FMP loop closing, and practices delivering successful outcomes elsewhere should be simultaneously considered for adoption or adaptation.

10. Be the program you say you are: An FMP is, at core, a matter of trust. When it operates in a way consistent with its stated mission, goals, and processes trust in it is likely to build and strengthen. Given the primacy of its mission and the dual newness and vulnerability of many participants, an FMP is also delicate and consequential. So walking the talk is essential. An FMP should only offer what it should and can provide, should not raise expectations it cannot or should not fulfill, and should make it a priority to deliver what it has offered.

Table 7, below, summarizes these ten guidelines that surfaced as FMP was operationalized.

Table 7: Ten Guidelines

\begin{tabular}{|ll|}
\hline 1. & Put someone in charge \\
\hline 2. & Anchor it in the faculty \\
\hline 3. & Give all a role to play \\
\hline 4. & Ensure it is possible and important to participate \\
\hline 5. & Balance formal structure with spontaneous interaction \\
\hline 6. & Train participants and communicate 360 \\
\hline 7. & Make the tough calls \\
\hline 8. & Have no assumptions \\
\hline 9. & Adapt the mechanism \\
\hline 10. & Be the program you say you are \\
\hline
\end{tabular}




\section{LIMITATIONS AND IMPLICATIONS FOR FUTURE RESEARCH}

The Literature Review section of this paper explained that the existing research tends to address characteristics of effective mentoring programs and their participants, advocacy and reservations about mentoring programs, and examples of specific mentoring programs. It further pointed out that websites of several colleges and universities which have faculty mentoring programs contain publicly available program descriptions and guidelines for their programs' participants.

That research base, though, is far less abundant in covering the steps involved in developing and optimizing an FMP, if and how the various FMPs identified on the websites are operating as described, what the genesis of and buy-in for the various FMPs were, who is leading and participating in the various FMPs, whether and what kind of assessment the various FMPs perform, and what outcomes the various FMPs are delivering. This paper provides that kind of information, but it is only one first-hand study of only one FMP. Reporting on similar aspects of other programs might provide additional perspective useful to those contemplating efficacy of a mentoring program at their own institutions, and to those engaged in management education.

\section{ALL ABOARD}

The FMP whose development, implementation, and outcomes are presented in the paper and summarized in Table 8, below, is operational today and continues to self-assess and reflectively adapt. Interestingly, although this FMP progressed through its various phases guided primarily by disciplinary expertise, practitioner experience, and resolve of its faculty architects, several emergent aspects that appear to optimize it are consistent with those Boyle and Boice's study found to be most constructive some 15 years ago: formal structure, strong participation, mentor paired with mentee from a different department, mentor of rank senior to mentee, and group meetings for all participants.

The time-tested nature of such features suggests they are among those others designing an FMP might find effective. Given complexity undertaking an FMP is likely to entail, such consistencies may be even more valuable in charting the way forward. Similarly, clarity of charge and singularity of vision, steadfastness in aligning those to bona fide developmental interests institution and participants share, designation of FMP created to further those as significant, and articulating that FMP does not replace or eliminate programmatic and administrative roles of Department Chairs and Deans, may also enhance FMP durability, reach, and results. Saliency of having such foundations to consider is underscored by McClurken's caution that existence of a mentoring program does not guarantee it is effective (2009).

Is the effort involved in creating a program where effective mentoring does occur worth it? In the end, that is perhaps most determined by those its intention is to serve. Comments by three mentees and by one former mentee now a mentor, each reflecting on the FMP this paper focuses on in a different year, summarize the potential breadth of benefits to be derived; no comments were received indicating anything other than benefits were derived:

- $\quad$ FMP Mentee, 2010: "One of the most beneficial aspects of the mentoring program was access to someone who was always willing to provide thorough and thoughtful direction - whether it was on student-related, pedagogical issues or career development issues. No question seemed too insignificant or too large - it was always addressed with very careful thought and consideration. In addition to the assigned mentor, I also like the group lunches which allowed us to get to know the other mentors as well. The mentorship program led to a strong sense of Camaraderie... It brought us together as cohorts with a common purpose and strengthened ties among new faculty, as well as with faculty who have been at Ramapo for a longer time."

- $\quad$ FMP Mentee, 2011: "When interviewing new faculty we should mention this program and provide testimonials. People thinking of joining us would be impressed. It is scary being the new person and knowing a welcoming/helpful program exists will alleviate this concern."

- $\quad$ FMP Mentor (Former Mentee), 2012: "The mentoring program was invaluable to me as an untenured faculty member. I want now to pay it forward; it's my turn to give back." 
- $\quad$ FMP Mentee, 2013: "I have been at and know people at lots of schools. None have any program like this. Some say they have mentoring programs but the mentors aren't available, they don't really meet, and nothing much happens. I am so grateful for our mentor program. Don't change a thing."

\section{CONCLUSION}

In conclusion, mentoring seems to be facilitated when those collectively engaged in shared outcomes collaboratively conceive, launch, participate in and enliven a win-win model they feel ownership of and actively support. The model finds a sustainable balance between structure and spontaneity, and between traditional and innovative elements, reflective of and resonant with its stakeholders. That is, on-boarding appears to be optimal when all are aboard.

Table 8: Summary - A Model For Win-Win Faculty Mentoring

\begin{tabular}{|l|l|}
\hline \multicolumn{1}{|c|}{ Attribute } & \multicolumn{1}{c|}{ Operationalization } \\
\hline Goals and Objectives & Development, support, retention, acculturation, community \\
\hline Program Communication & Documents, meeting calendar, and links are given to all faculty \\
\hline Program Administration & $\begin{array}{l}\text { Faculty approves program and selects faculty member to chair; participants are trained } \\
\text { upfront; Dean/Chairs are included }\end{array}$ \\
\hline Expectations for Participants & Pairs define salient outcomes within formal program guidelines \\
\hline Attributes of Mentors & Mentors are tenured and not from mentee's department \\
\hline Attributes of Mentees & Mentoring is formal years 1 and 2; it is informal years 3-tenure \\
\hline Matching Mentor with Mentee & $\begin{array}{l}\text { Dean and Search Chair are consulted re: mentee needs; 1st year mentor pairs are matched; } \\
\text { 2nd year mentees request mentors }\end{array}$ \\
\hline Meetings & $\begin{array}{l}\text { Mentor pairs meet pre- or post- collective sessions for all faculty; mentor and mentee off- } \\
\text { record observe each other teaching }\end{array}$ \\
\hline Including Non-Paired Faculty & $\begin{array}{l}\text { All tenured can mentor, all untenured can be mentored, all faculty can attend collective } \\
\text { sessions, all sessions are confidential }\end{array}$ \\
\hline Outreach & $\begin{array}{l}\text { Co-host sessions with relevant standing Committees, include Dean and Department head } \\
\text { in sessions that inform or recognize }\end{array}$ \\
\hline Program Feedback & $\begin{array}{l}\text { Survey participants anonymously at year-end, share results in annual report, debrief } \\
\text { mentors and mentees 1-1 at midyear }\end{array}$ \\
\hline Program Revision & Consider and continually implement all relevant suggestions \\
\hline
\end{tabular}

\section{AUTHORS' INFORMATION}

Susan Eisner is a Professor of Management, in Ramapo College's Anisfield School of Business; she co-founded and Chairs its Faculty Mentoring Program. Before teaching she held key positions in a leading television station, prominent health care foundation, national political party, and Presidential campaign. Her graduate degree is from Harvard's Kennedy School, where she was an Administration Fellow. Her interests include leadership, organizational behavior, interpersonal workplace skills, diversity/age/gender, and entertainment/media management. She has received the College's Award for Faculty Excellence, and the School's Outstanding Teacher Award. Her biographical recognitions include Who's Who in the World, Who's Who in America, and Who's Who Among America's Teachers. Susan Eisner, M.P.A, Professor of Management, Ramapo College of New Jersey, Anisfield School of Business, Room 503, 505 Ramapo Valley Road, Mahwah, New Jersey 07430 USA. Email: seisner@rampo.edu.

\section{REFERENCES}

1. Allen, T, Finkelstein L., \& Poteet M. (2009). Designing workplace mentoring programs: An evidencebased approach. Hoboken, N.J.: Wiley-Blackwell.

2. Bell, A. \& Treleaven, L. (2011, May). Looking for professor right: Mentee selection of mentors in a formal mentoring program. Higher Education, 61 (5), 545-561.

3. Borders, L., Young, J., Wester, K., Murray, C., Villalba, J., Lewis, T., \& Mobley, A. (2011, March). Professional development: Mentoring promotion/tenure-seeking faculty. Counselor Education \& Supervision, 50, 171-188. 
4. Boyle, P., \& Boice, B. (1998, Spring). Systematic mentoring for new faculty teachers and graduate teaching assistants. Innovative Higher Education, 22 (3), 157-177.

5. Cariaga-Lo, L., Dawkins, P., Enger, R., Schotter, A., \& Spence, C. (2010, Summer). Supporting the development of the professoriate. Peer Review, $A A C \& U, 19-22$.

6. Carter, N., \& Silva, C. (2010). Pipeline's broken promise. New York, N.Y.: Catalyst.

7. Chao, Georgia T. (2009, June). Formal mentoring: Lessons learned from the past. Professional Psychology: Research \& Practice, 40 (3), 314-320.

8. Derven, M. (2008, April). Management onboarding. T\&D, 49-52.

9. Dubrin, A. (2013). Leadership: Research findings, practice, and skills (7 ${ }^{\text {th }}$ ed.). Mason, OH: SouthWestern, Cengage Learning.

10. Kanuka, H. (n.d.). Does mentoring new faculty make a difference? Learning Commons. Retrieved from http://www.lehigh.edu (2012, November 29).

11. McCauley, R. (2007, Summer). Building a successful mentoring program. Journal for Quality \& Participation, 30 (2), 17-19.

12. McClurken, Jeffrey W. (2009, October 14). Why not to set up a formal new faculty mentoring program, The Chronicle of Higher Education/Blogs.

13. Mellon Academic Mentoring Support Project. (2003, December 16). Faculty mentoring paper summary. USC Center for Excellence in Teaching. Retrieved from info.marshall.usc.edu.

14. Ramani, S., Gruppen, L., \& Kachur, E. (2006). Twelve tips for developing effective mentors. Medical Teacher, 28 (5), 404-408.

15. Robbins, S., \& Judge, T. (2013). Organizational behavior (15 ${ }^{\text {th }}$ ed.). Upper Saddle River, N.J: Pearson/Prentice Hall.

16. Savage, H., Karp, R., \& Logue, R. (2004, Winter). Faculty mentorship at colleges and universities. College Teaching, 52 (1), 21-24.

17. Sorcinelli, M., \& Jung, Y. (2007, November/December). From mentor to mentoring networks; mentoring in the new academy. Change, 39 (6), 58-61.

18. The 10 commandments of employee onboarding. (n.d.). CareerBuilder.com (2013, February 16 


\section{APPENDIX}

Faculty Mentoring Program Checklist, Anisfield School of Business, Ramapo College of NJ

FMP Mentor Pairs: Mentor schedules 3 benchmark meetings each year to support mentee's progress toward meeting performance goals mentee has established. Meeting 1 (M1) is at start of academic year (September), Meeting 2 (M2) is at start of next semester (February), and Meeting 3 (M3) is at end of the academic year (May). * indicates this should be included in that meeting.

Review FMP together; mentor invite mentee to follow up at any time

Confirm mentee has background on personnel timelines and performance expectations for teaching, scholarship, and service for the year; verify mentee is familiar with the Faculty Handbook; offer mentee feedback on portfolio s/he prepares for his/her next personnel review

Clarify mentee's goals in teaching, scholarship, and service for the academic year; mentee's progress to goals; and ways to facilitate future mentee progress

Schedule an off-record confidential classroom visit of mentee by mentor for Fall semester, and a joint debriefing immediately after

Schedule off-record confidential reverse classroom visit of mentor by mentee (or of a tenured faculty member mentor recommends) for the Fall semester, and a debriefing immediately after Query what kind of support mentee would find most valuable and provide direction for accessing that support; ask if mentor anticipates any difficulties or has any concerns, provide counsel if possible, and refer if helpful

Query what questions mentee has, and provide or refer for answers

Volunteer to provide feedback on any written performance assessments mentee has received (e.g. formal classroom visits by Dean/peer/other, student opinion surveys, personnel committee or other evaluative letters)

Optional (mentee's choice): Schedule an off-record confidential visit of mentee by mentor in Spring semester, and a joint debriefing immediately after

Optional (mentee's choice): Schedule an off-record confidential reverse classroom visit of mentor by mentee (or of a tenured faculty member mentor recommends) in Spring semester, and a debriefing immediately after

\section{Collective Sessions (Dates To Be Confirmed by FMP Chair)}

Welcome Reception: All FMP participants

Mentor Roundtable: Mentors and FMP Chair before or after Welcome Reception

FMP/ASB Personnel Committee Orientation Session: All ASB faculty

Mentor Pair: Each FMP pair meets for $1 / 2$ hour before or after Orientation Session

FMP Teaching Roundtable 1: All ASB faculty

Mentor Pair: Each FMP pair meets for $1 / 2$ hour before or after Teaching Roundtable

Mentor Debrief: Mentors and FMP Chair (1-1 or roundtable)

Mentee Debrief: Mentees and FMP Chair (1-1 or roundtable)

FMP Teaching Roundtable 2: All ASB faculty

Mentor Pair: Each FMP pair meets for $1 \frac{1}{2}$ hour before or after Teaching Roundtable

FMP Open Roundtable: All ASB faculty

Mentor Pair: Each FMP pair meets for $1 / 2$ hour before or after Open Roundtable

End-Year Celebration/Lunch: All FMP participants 


\section{ENDNOTES}

${ }^{\mathrm{i}}$ The Anisfield School of Business at Ramapo College of New Jersey.

${ }^{i i}$ Retrieved on December 10, 2012 from http://www.merriam-webster.com/dictionary/mentor.

iii Bryant, Adam. (2012, December 8). The New York Times.

${ }^{\text {iv }}$ Bryant, Adam. (2013, March 16). The New York Times.

${ }^{v}$ Ramapo College is included among the top schools in U.S. News \& World Report's America's Best Colleges (ranks 6 out of 42 in the Best Regional Universities, North category), those named to Kiplinger's Personal Finances list of 100 best values in public college, those The Princeton Review recommends as among the Best in the Northeast/Best Northeastern Colleges, those included in The Templeton Guide Honor Roll for Character-Building Colleges, and those featured on CollegesofDistinction.com for excellence in studentfocused higher education; Ramapo College's Anisfield School of Business is among the less than 5\% of business schools worldwide accredited by AACSB ( $\mathrm{http}: / / \mathrm{www}$. ramapo.edu/about/profile/accolades.html\# on February 23, 2013).

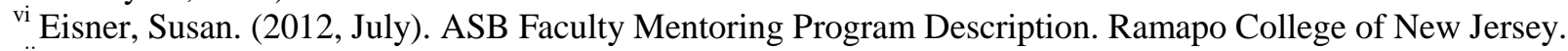

${ }^{\text {vii }}$ Assessment results are reported in this paper (see Operationalizing a Faculty Mentoring Program).

viii Conversations 2005-2013 between FMP faculty participants and FMP Chair Susan Eisner.

ix "A Model for Win-Win Interviewing: The Five C's" (Society for Advancement of Management (SAM) Management in Practice Number 1, 2005), "C-Change? Generation $\mathrm{Y}$ and the Glass Ceiling" (SAM Advanced Management Journal, Vol. 74, Number 1, Winter 2009, pp. 13-28), "Reflections on Leadership" (SAM Advanced Management Journal, Volume 76, Number 4, Autumn 2011, pp. 47-61), and "Leadership and Gender" (SAM Advanced Management Journal, Volume 78, Number 1, Winter 2013, pp. 26-41).

${ }^{x}$ W. Sauser and R. Sims. (2012). Charlotte N.C.: Information Age Publishing.

${ }^{x i}$ The New Pathways: Faculty Careers and Employment for the $21^{\text {st }}$ Century project sponsored by the American Association for Higher Education in the late 1990s cited by Savage et al. is further described in Borders et al., 2011.

xii Representative resources on mentoring publicly available at higher education websites in 2012- 2013 include:

a) Brown University. One-to-one faculty mentoring program guide for participants.

www.brown.edu/Administration/Provost/Advance/2011.Mentor.Guide.pdf; b) City University of New York. Faculty mentoring program. http://www.cuny.edu/research/faculty-resources/internal-fundingprograms/FacultyMentorship; c) Cornell University, Johnson Graduate School of Management. Mentoring new faculty. http://www.2.johnson.cornell.edu/administrativeservice/academic/faculty/mentoring.html; d) Harvard University. Faculty mentoring resources. http://www.faculty.harvard.edu/development-andmentoring/faculty-mentoring-resources; e) Lock Haven University. Faculty mentoring project. http://www.lhup.edu/provost/mentor-project/html; f) Northern Illinois University. New faculty mentoring program. http://www.niu.edu/facdev/services/newfacmentoring.shtml; g) Penn State College of Education. Faculty mentoring program. http://www.ed.psu.edu/general/mentoring.asp; h) Rider University. Faculty mentoring program recommendations. http://01f1c64.netsolhost.com/faculty mentoring rec.pdf; i) Ripon College. Academics/faculty mentor program. http://ripon.edu/academics/facdev/MentorProgram.html; j) University of Albany. Mentoring best practices: A handbook. http://www.albany.edu/academics/mentoring.best.practices.toc.shtml; k) University of California, San Diego. Academic affairs/faculty programs/faculty mentoring program.

http://academicaffairs.ucsd.edu/faculty/programs/faculty-mentoring-program.html; 1) University of Kentucky. A guide to mentoring. www/uky.edu/Provost/APFA/Department-Chairs/CLAHS.mentoring.handbook.pdf; m) University of Minnesota. Faculty mentoring at the University of Minnesota.

http://www.academic.umn.edu/provost/faculty/pdf/PELMentorReport.pdf; n) University of Pennsylvania. Quick resource guide to mentoring best practices at Penn. http://www.upenn.edu/provost/images/uploads/Faculty.Mentoring; o) University of Rhode Island. Faculty mentoring handbook. www.uri,edu/advance; p)University of Southern California. Exemplary junior faculty mentoring programs. info.marshall.usc.edu/faculty/mentoring. 
xiii The author of this paper was among Task Force members, has served as a mentor in the FMP it conceived from the start, was selected by the faculty to Chair the operationalized FMP, and has remained as Chair in the years since.

${ }_{\text {xiv }}$ ASB FMP Chair does not receive reassigned time or stipend, nor do other ASB FMP participants. 